\title{
Searching for the Kitchen in the Early Roman Phase of the 'Hellenistic' House at Nea Paphos (Cyprus)
}

\author{
MONIKA WIĘCH
}

\begin{abstract}
This paper presents the first preliminary study of cooking wares from the early Roman phase of destruction of the 'Hellenistic' House at the Nea Paphos site of Maloutena. The collection of fifteen cooking vessels was discovered in situ in room 22, between and in front of the stone blocks - most probably table supports; another two were found in room 23. The assemblage contains mostly deep, globular pots from Cyprus, but also Italian lids and an orlo bifido pan, as well as two Aegean cooking vessels (one globular pot and one baking dish). The large quantity of cooking pottery allow us to consider a kitchen function for rooms 22 and 23.
\end{abstract}

Keywords: early Roman Cyprus, Nea Paphos, 'Hellenistic' House, cooking ware, Cypriot cooking ware, Aegean cooking ware, Pompeian red ware

Monika Więch, Institute of Mediterranean and Oriental Cultures, Polish Academy of Sciences, Warszawa; mwiech@iksio.pan.pl

Repeated destruction by earthquakes in ancient Nea Paphos created some well-dated closed archaeological deposits also in the residential quarter, excavated by the Polish Archaeological Mission of the University of Warsaw at Kato Paphos. Some of them were identified during archaeological investigation in the area of the 'Hellenistic' House (hereafter $\mathrm{HH}$ ), situated in insula 10A' between the north-south streets nos 10 and 9 and the east-west streets A and A'. This paper aims to present one such deposit - namely cooking vessels found in situ in rooms 22 and 23, as well as interpret the function of the rooms.

\section{ARCHITECTURAL CONTEXT}

The analysed rooms are located in the western part of the $\mathrm{HH}$, in a row of small cubicles (nos 20-23), north of the main hall (no. 10) and western courtyard (no. 13), with room 11 in between (Fig. 1). It is worth noting that rooms 20-23 were not situated on the edge of the building and that two rows of chambers should still be unearthed to reach the north border of the insula (so far $c$. two-thirds of the area occupied by the HH has been excavated). 


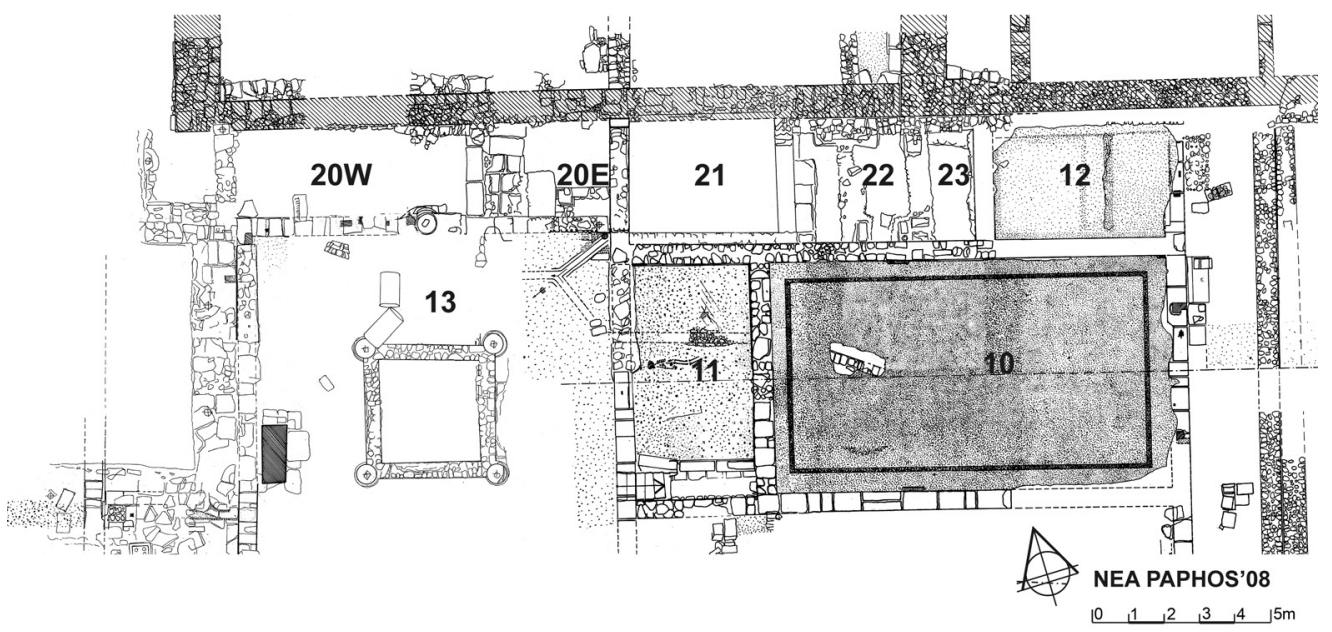

1. North-western part of the 'Hellenistic' House (Based on: Mazanek 2014: Fig. 1; drawing: S. Medeksza, A. Brzozowska).

Due to the several factors the north-western part of $\mathrm{HH}$ was well preserved. First of all, the second century $\mathrm{AD}^{1}$ earthquake rendered this area unusable, therefore it was not re-used in later times. Moreover, it was originally on a much lower level than the eastern wing of the building and therefore the Villa of Theseus, whose southern edge reached this area, did not cut the structures belonging to the 'Hellenistic' House.

Rooms 22 and 23 most probably functioned together as a single unit since the wall between them was hardly raised above floor level. The entrance to room 22-23 was originally located in the northern wall of room 22, but during the early Roman period the door, with a step in front of it, was no longer in use. Another doorway could have opened from room 21. The wall preserved between room 21 and 22 seems to have been rather low, enabling communication. ${ }^{2}$

\section{THE ROOMS}

Room 22 is 3 metres long $(\mathrm{N}-\mathrm{S})$ and 3.10 metres wide $(\mathrm{E}-\mathrm{W})$. Two large rectangular stone blocks ( 0.5 metres high) unearthed by the southern wall were interpreted as table supports. ${ }^{3}$ No remains of a tabletop were found, hence it was most likely made of wood. A clay floor was discovered $1.45 \mathrm{~m}$ below the surface of the earthquake-related debris. The sealed deposit of fifteen cooking ware vessels (Figs 3, 5-6) was found beside the south wall, directly above the floor surface. This layer was divided into several contextual units: no. 68 (between blocks), no. 69 (directly north of the blocks), no. 70 (west of

\footnotetext{
1 Hayes 1997: 536.

${ }^{2}$ Henryk Meyza, personal communication.

${ }^{3}$ Daszewski et al. 2010: 511, Fig. 8.
} 


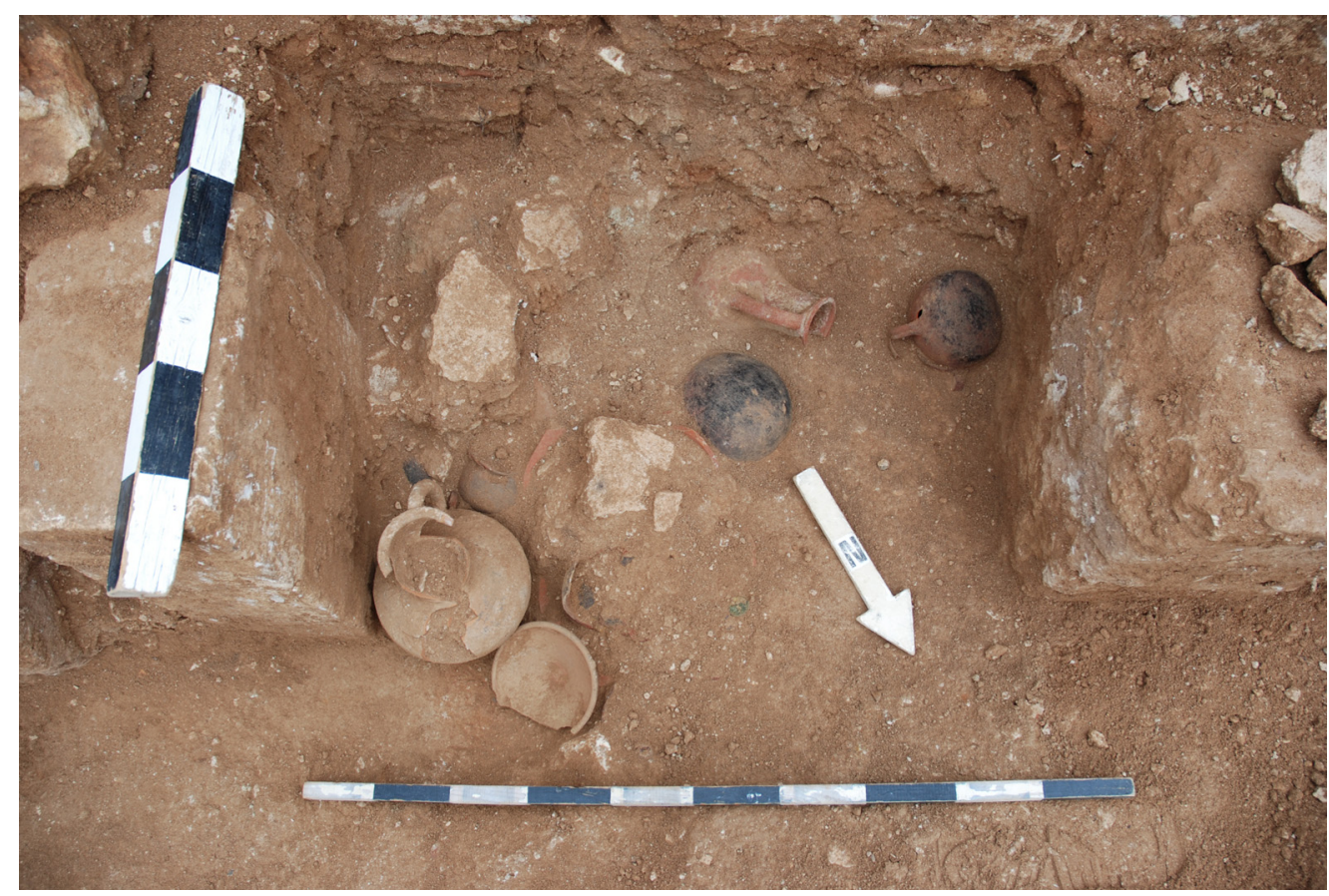

2. Deposit of vessels between the two table supports in room 22 of the 'Hellenistic' House (Phot. W. Machowski).

the blocks) and no. 67 (north and west of the blocks), although they formed most likely a single stratigraphic layer. Most of the artefacts came from between the presumed table supports (Fig. 2). ${ }^{4}$ Besides the above-mentioned cooking pots the deposit also contains a few transport amphorae (Mau 27/28, Sub-Koan, Carrot Amphora and Pompeii V types), ${ }^{5}$ table ware (Cypriot sigillata: forms P37 and P10; Italian sigillata: type Consp. 3; eastern sigillata A: forms 4 and 22), ${ }^{6}$ plain ware (two jugs and three small inturned bowls or lids), ${ }^{7}$ colour-coated jug, two lamps, a collection of glass vessels (mainly large bottles serving as containers, several big plates and drinking vessels), lead weights, a mirror and some native sulphur. ${ }^{8}$ The earliest from this assemblage are the Hellenistic colour-coated jug and the lamps, ${ }^{9}$ and the most recent are the Mau 27/28 and Sub-Koan amphorae, dated to the early Roman period.

Room 23, situated further to the east, was smaller than the previous one. Its fill (contexts nos 78 and 79) and the level of the floor seem to correspond to those of room 22 (both

4 Daszewski et al. 2010: 511.

5 Reynolds 2005: 586-589; Peacock, Wiliams 1986: 107-108.

${ }^{6}$ Hayes 1991: 32-50, Figs 17-20; Ettlinger et al. 1990: 56, Fig. 3.

7 Hayes 1991: 18-19, 65-67, Figs 10, 44.

8 Daszewski et al. 2010: 511; Mazanek 2014: 283.

9 Daszewski et al. 2010: 511. The lamps dated to the early-first century AD. 
floors dated by the pottery to the second century AD). ${ }^{10}$ One broken but restorable cooking pot (Fig. 4:8) was found in a layer of early Roman debris, just like one intact pot (Fig. 4:9) set into the clay floor. The last mentioned pot could belong to the same period as the vessels from room $22 ;{ }^{11}$ its function was, however, different. It may have been used as a container for rubbish or water drained from the floor after cleaning of the chamber. ${ }^{12}$

Large quantity of cooking ware vessels indicates kitchen or pantry function of the room. However, there were no remains of a hearth or oven in room 22-23, which could serve to prepare food. Since the floor in room 22 (context no. 82) yielded a large amount of charcoal, it may have been furnished with portable braziers, grates or supports made of clay or metal, which were fuelled with kindling or charcoal. ${ }^{13}$ Such equipment were commonly used by Greeks and Romans, but no remains of them were found in room 22-23 as well.

A close parallel corroborating identification of room 22-23 as a kitchen can be found not in the nearby House of Dionysos, or on Cyprus, but at Knossos. A unit of three small rooms (with a floor dating to the Neronian period) was discovered in the East House at the site. It served the combined function of storage and preparation of food. Several amphorae and cooking pots were found there in rooms I and III. Room II did not contain any storage facilities, but a hearth and ash deposit. Originally, these three rooms created a single functional unit and only in a later phase was the door between rooms I and II walled up, presumably to protect the contents of the store. ${ }^{14}$ The most significant difference between the complex from the East House at Knossos and room 22-23 of the 'Hellenistic' House at Nea Paphos is that in the latter example no clear evidence of cooking activity was observed.

\section{COOKING WARES}

Cooking ware is defined as pottery used for actual cooking. Three interrelated criteria function, form and material - determine the classification of a vessel.

To define the function one needs to analyse the archaeological context as well as signs of use visible on the surface of the pottery (for example burning or sooting from the hearth). In this context it is important to underline that about half of the vessels presented in the catalogue have more or less blackened walls and/or bottoms.

As for the form of the vessels, the presented assemblage is specific, since it is only a part of set of the kitchen utensils used for cooking. It contains thirteen deep, narrow-mouthed globular pots, two flat baking dishes (or pans) and two lids. Although two casseroles were found in the layers belonging to the deposit as well, their fragmentary state of preservation suggests that they are residual sherds, not part of a set of vessels destroyed by the earthquake.

\footnotetext{
${ }^{10}$ After E. Papuci-Władyka, E. Marzec, unpublished field documentation.

11 Hayes 1991: 81, 83, Figs 31:1, 3-4; 34:10-11.

12 Daszewski et al. 2010: 513.

13 Ault 2015: 209.

14 Sackett, Jones 1992: 34, P1. 16(b).
} 
Deep, narrow-mouthed globular pots were the most popular vessels used for cooking throughout the eastern Mediterranean. They were best suited for preparing dishes that required slow cooking without a significant loss of water, such as soups or legumes. Casseroles, on the other hand, with their open mouths and wide bodies, probably served to boil or stew meat, fish or large vegetables. In contrast to the deep pots, they were present in significant numbers only at Greek settlement sites. ${ }^{15}$ In the area of Polish excavations at Nea Paphos in most of the contexts casseroles were equally numerous, if not more frequent than the deep, narrow-mouthed pots. ${ }^{16}$

Pots from room 22-23 represent a few different fabrics, not only from Cyprus but also imports from Asia Minor, the Aegean region and Italy. Still, all these fabrics have features specific for cooking wares.

As is well known, reaction to thermal changes is an important factor for cooking ceramic containers. Thermal stress is one of the reactions of ceramics, induced by sudden temperature change. Stresses are caused by differential thermal expansion, but they may be even more severe in the process of cooling. Thermal shock was reduced by decreasing wall thickness and by modifying the pot shape to eliminate angles, but the composition, particularly inclusions in or added to clay, were of greatest importance. During the Roman period cooking pots were made in specialised fabrics with a high percentage of relatively coarse temper. The fabrics are often sandy and rich in quartz. ${ }^{17}$ Clay temper may have also included grog, calcite, crushed burned shell, zircon, rutile, feldspar, augite and hornblende. ${ }^{18}$

\section{CYPRIOT COOKING WARE}

Twelve intact and broken but restorable deep globular pots found in room 22-23 most probably represent local Paphian production (Figs 3-5). The fabric is described as hard, well-fired, reddish-brown in colour, non-micaceous, but with small white inclusions, most probably limestone. ${ }^{19}$ All examples had thin, non-ribbed, walls and sloping rims, as well as a 'ledge' on the inner side of the neck, to support a lid, more or less strongly delineated. A coarsening in the form of cusps of clay, which may have served an anti-slip function, appeared on most vessels, on the outside of the bottom.

Usually the assemblage of early Roman Cypriot cooking ware includes wide-mouthed, shallow casseroles, narrow-mouthed deep pots - usually small and one-handled, jugs with a concave bottom, and lids. It seems that Cypriot workshops did not produce flat-based pans, but demand for this type of vessel was covered by Asia Minor imports. Apart from the slight coarsening on the bottom, the outside surface of early Roman cooking pots is

\footnotetext{
15 Berlin 1993: 41-42.

16 Personal observation made during 2010-2016 campaigns.

17 Winther-Jacobsen 2010: 51.

18 Rice 1987: 228-229.

19 Hayes 1991: 81.
} 
usually plain and well-finished, especially in comparison to the rather rough surface of Hellenistic vessels.

Based on the number and shape of handles and the capacity of the vessels, pots from room 22-23 can be divided into two basic groups. Nine examples featured one vertical handle (Figs 3:1-7, 4:8-9), while the remaining three had two handles, also vertical (Fig. 5:10-12).

Among one-handled pots two main types can be distinguished, on the basis of rim and handle shape. Eight examples, representing the first type, were characterised by their small capacity, 1 liter on average ( 0.8 to 1.3 liter), a not-too-large, bulging belly and a simple rim outcurved or thickened at the lip. The handles were solid, with a single groove in the middle (except for the oval-sectioned handle of pot no. 5), which is typical not only for small narrow-mouthed pots, but also for shallow casseroles of the early Roman period. In the House of Dionysos, this type of cooking pot is dated contextually from the late first/early-second to second century AD. The only pot (no. 9) belonging to the second type, with a more developed shape of the rim and a strap handle bearing two grooves was much bigger (c. 3 liters of capacity). The strap handle with two or three grooves is characteristic only for this type of deep globular pots and for cooking ware jugs. Although the pot was found not on the floor or in the rubble fill, but set into the floor, it can be dated to the early Roman period. ${ }^{20}$ It is likely that this type of pot, often also two-handled, came from a different workshop than the other described vessels.

The two-handled deep globular pots (Fig. 5:10-12) were slightly larger and more squat (from 1.9 to 3 liters capacity) with a short neck and sloping rim. We can distinguish two types on the basis of rim shape: with plain rim and with a rim flattened from the top and incurved at the lip. Both can be dated to the early Roman period. ${ }^{21}$

\section{AEGEAN COOKING WARE}

Aegean cooking ware were extremely popular in Greece, in western Asia Minor, in the Adriatic basin and throughout the Eastern Mediterranean, during the second and third centuries AD. They were present less frequently in Cyprus - as we can see in the example of material from Nea Paphos - and on the Levantine coast. ${ }^{22}$ Finds from underwater excavations of shipwrecks have confirmed that this category of vessels was transported as cargo, for example, together with Asia Minor eastern sigillata B. ${ }^{23}$

During excavations in the Athenian Agora two types of deep cooking pots, casseroles with carination on the body and trefoil jugs were identified as the main shapes of Aegean

\footnotetext{
${ }^{20}$ Hayes 1991: 81, 83, Figs 31:1, 3; 34:10, 11. According to J.W. Hayes, this shape belongs to the early Roman series and is present on the site since Augustan times (or somewhat earlier).

${ }^{21}$ Hayes 1991: 81-83.

22 Hayes 1991: 80.

23 Istenič, Schneider 2000: 341-342.
} 
cooking ware. ${ }^{24}$ G. Lüdorf in her typology of the Roman and the early Byzantine pottery from western Asia Minor classified five different shapes of casseroles and six of deep pots of Aegean cookware, ${ }^{25}$ whereas four basic forms of deep pots of Aegean cooking ware were distinguished in the ceramic material from the destruction layers at the Villa Dionysos at Knossos, dating to the second and third centuries AD.

Only one of the deep pots from the room 22 (Fig. 6:13) should be considered as an Aegean import. A light, orange-pink fabric with traces of mica, the outside surface fired to smoky-grey (except for the bottom), wide, flat rim, two small handles and shallow grooves on the belly point to the origin of the vessel. ${ }^{26}$ The same coarsening, as was observed on Cypriot pots, in the form of cusps of clay, appeared on the outside of the bottom.

The Aegean cooking pot from room 22 of $\mathrm{HH}$, should be classified as Knossos type 2 or Lüdorf type T I/1 (Kochtopftypus T I/1). ${ }^{27}$ Deep globular pots of this type, as well as shallow casseroles and jugs with a trefoil rim, made of the same micaceous fabric, were present in most of the early Roman contexts in the area of the Polish excavations, although in the relatively small quantities. ${ }^{28}$ The small number of the Aegean deep pots and casseroles coming from the Polish excavations in the Maloutena area and Cypriot excavations at the House of Dionysos (Nea Paphos) ${ }^{29}$ in comparison to the Villa Dionysos at Knossos, where they practically replaced local products, suggests that there was no organised importation of the ware as a plain cooking utensil. Aegean pots possibly served as containers for valuable goods rather than vessels intended for cooking.

The thick-walled dish (Fig. 6:14), found almost intact close to the supports of the table, also belonged to Aegean cooking ware. The ware is characterised by very coarse fabric with sandy and crystalline inclusions, as well as flecks of mica. These types of vessels heavy, flat-bottomed with short simple walls, usually with one tubular handle - probably functioned as baking dishes. ${ }^{30}$ The inner surface of the vessel is covered with a thin, light red or orange slip, powdery to the touch, which may have prevented food from sticking to the surface. The bottom is coarsened on the outside, sometimes additionally finished with grains of sand stuck on the surface (sanded).

Examples of such vessels come from Athenian Agora, from layers dating to the first half of the first century AD. ${ }^{31}$ On the basis of Lüdorf's typology, the discussed baking dish should be classified as type P I/1 (Pfannentypus PI/1), dating to the first century AD. ${ }^{32}$

\footnotetext{
24 Robinson 1959: 53-56, Pls 11, 72.

25 Lüdorf 2006: 43-51, Figs 5-12.

26 Robinson 1959: 53-56, Pls 11, 72; Hayes 1983: 123.

27 Hayes 1983: 105, Fig. 5:58-59; Lüdorf 2006: 47, Fig. 7:T7, Pl. 3.

28 Personal observation made during 2010-2016 campaigns.

${ }^{29}$ Hayes 1991: 80.

30 Berlin 1993: 43.

31 Robinson 1959: 33, G113-115, Pls 7 and 72.

${ }^{32}$ Lüdorf 2006: 41-42, Fig. 1:P6, P1. 1.
} 
Scholars have suggested Phocaea in western Asia Minor and, perhaps, the Thracian coast, as the production centre of Aegean baking dishes. ${ }^{33}$

\section{ITALIAN COOKING WARE}

Among other imported cooking ware vessels attested in $\mathrm{HH}$ - in a small but constant number - one should enumerate Italian imports of pans and lids, namely Pompeian red ware and, related with it, an orlo bifido class. ${ }^{34}$ In material from room 22-23, Italian products are represented by at least two vessels: a large version of an orlo bifido pan (Fig. 6:17) and a wide-mouthed lid (Fig. 6:16). The fabric of both vessels is very similar, close to the first two fabrics described by Peacock in his monograph. These fabrics stand out by their 'black sand' inclusions, identified as volcanic. ${ }^{35}$ The form of the above-mentioned lid is well attested in the repertoire of Pompeian red ware as defined by Goudineau, as well as among Italian cooking ware from the House of Dionysos (Nea Paphos). ${ }^{36}$ The Pompeian red ware and an orlo bifido pans, with a flat bottom and narrow groove on the rim to support a lid, are well known from early Roman sites throughout Italy and Europe. The most probable place of their manufacture is Campania.

The origin of the second lid (Fig. 6:15) found in the deposit remains unidentified, although it is certain that it was imported. The shape of the vessel, featuring a plain rim and small ring knob, suggested an Italian workshops. However, a rather fine, pinkish fabric with small white and red inclusions seems to correspond to African products. The closest analogy for the form comes from V. Di Giovanni's typology of Roman period kitchen pottery from Campania (type 2421c and 2421d). ${ }^{37}$

\section{CONCLUSIONS}

The analysed part of $\mathrm{HH}$ (room 22-23) functioned as a storage room closely related to the kitchen facilities. Although it produced a large number of cooking vessels, it is not clear whether these rooms served also as a cooking area, since neither any traces of a fixed hearth nor fragments of braziers were found there. Possibly, the kitchen proper in the early Roman period was located further to the north. The composition of the vessels' assemblage seems to corroborate this hypothesis, since it represents only a part of the standard set of ancient kitchen utensils. The absent large pots and in particular casseroles - a very common shape at Nea Paphos in the early Roman contexts - could have been stored in other parts of this kitchen complex. However, this hypothesis could be verified

33 Istenič, Schneider 2000: 343; Hayes 2000: 290; 2009: 13.

34 Personal observation made during 2010-2016 campaigns.

35 Peacock 1977: 146, 149-154.

36 Goudineau 1970: 168, P1. II:18; Hayes 1991: 79, Fig. 27:6.

${ }_{37}$ Di Giovanni 1996: 97-99, Fig. 25; compare: Hayes 2009: 9, 17, Fig. 16:75. An example from Castelporziano excavations belongs to an African Black-Top lid. Context dated do mid-first century AD; Hayes 1972: 205-207, Fig. 36 top, ARS Form 192. 
only through further excavations. Even though the function of room 22-23 is elusive, the well-dated, undisturbed deposit of vessels found there remains important for studies of locally-made Cypriot cooking ware.

\section{References}

Ault, B.A. 2015: Kitchens, [in:] Wilkins, J., Nadeau, R. (Eds), A Companion to Food in the Ancient World, Malden, MA-Chichester-Oxford, 206-211

Berlin, A.M. 1993: Italian Cooking Vessels and Cuisine from Tel Anafa, IEJ 43/1, 35-44

Daszewski, W.A., Meyza, H., Machowski, W., Papuci-Władyka, E., Rądkowska, J.K., Wasilewska, O. 2010: Nea Paphos, Season 2007, PAM XIX, 503-514

Di Giovanni, V. 1996: Produzione e consumo di ceramica da cucina nella Campania romana (II a.C. - II d.C.), [in:] Bats, M. (Ed.), Les céramiques communes de Campanie et de Narbonnaise ( ${ }^{\mathrm{er}} \mathrm{s}$. av. J.-C. - II ${ }^{\mathrm{e}}$ s. ap. J.-C.). La vaisselle de cuisine et de table. Actes des Journées d'étude organisées par le Cente Jean Bérard et la Soprintendenza Archeologica per le Province di Napoli e Caserta, Naples 27-28 mai 1994, Collection du Centre Jean Bérard 14, Naples, 65-103

Ettlinger, E., Kenrick, P.M., Roth-Rubi, K., Zabehlicky-Scheffenegger, S. 1990: Die Formen, [in:] Ettlinger, E. et al., Conspectus formarum terrae sigillatae Italico modo confectae, Materialien zur römisch-germanischen Keramik 10, Bonn, 51-146

Goudineau, C. 1970: Note sur la céramique à engobe interne rouge-pompéien (« Pompejanisch-roten Platten »), MEFRM 82/1, 159-186

Hayes, J.W. 1972: Late Roman pottery, London

Hayes, J.W. 1983: The Villa Dionysos Excavations, Knossos: The Pottery, ABSA 78, 97-169

Hayes, J.W. 1991: The Hellenistic and Roman pottery, Paphos III, Nicosia

Hayes, J.W. 1997: Comment, [in:] Hellenkemper Salies, G., Römischer Wohnluxus im griechischen Osten, JRA 10, 524-536

Hayes, J.W. 2000: From Rome to Beirut and beyond: Asia Minor and Eastern Mediterranean trade connections, RCRF 36, 285-297

Hayes, J.W. 2009: Castelporziano. Excavations at the Imperial Vicus 1985-7 and 1996-8. Trenches S and SA: pottery finds and lamps, Oxford

Istenic, J., Schneider, G. 2000: Aegean cooking ware in the Eastern Adriatic, $R C R F$ 36, 341-348

Lüdorf, G. 2006: Römische und frühbyzantinische Gebrauchskeramik im westlichen Kleinasien. Typologie und Chronologie, InternArch 96, Rahden

Mazanek, D. 2014: Preliminary Typology of Glass Vessels from the So-called Hellenistic House, Explored by the Polish Archaeological Mission in Nea Paphos (Cyprus), EtudTrav XXVII, 280-321

Peacock, D.P.S. 1977: Pompeian Red Ware, [in:] D.P.S. Peacock (Ed.), Pottery and Early Commerce. Characterization and Trade in Roman and Later Ceramics, London-New York-San Francisco, 147-162 
Peacock, W. 1986: Amphorae and the Roman economy: an introductory guide, London-New York

Reynolds, P. 2005: Levantine amphorae from Cilicia to Gaza: A typology and analysis of regional production trends from the 1st to the 7th centuries, [in:] Gurt i Esparraguera, J.M., Buxeda i Garrigós, J., Cau Ontiveros, M.A. (Eds), LRCW 1. Late Roman Coarse Wares, Cooking Wares and Amphorae in the Mediterranean. Archaeology and Archaeometry, BAR-IS 1340, Oxford, 563-611

Rice, P.M. 1987: Pottery Analysis. A Sourcebook, Chicago

Robinson, H.S. 1959: Pottery of the Roman Period. Chronology, Agora V, Princeton, NJ

Sackett, L.H., Jones, J.E. 1992: Excavation and Architecture, [in:] Sackett, L.H. et al., Knossos: from Greek City to Roman Colony. Excavations at the Unexplored Mansion II, The British School at Athens Supplementary Volumes 21, London, 1-58

Winther-Jacobsen, K. 2010: From pots to people. A ceramic approach to the archaeological interpretation of ploughsoil assemblages in Late Roman Cyprus, Babesch Supplements 17, Leuven-Paris-Walpole 
CATALOGUE 
1. Cooking pot, narrow-mouthed, plain slopping rim, triangular at the lip, centrally grooved handle and deep body, rounded bottom, thin-walled. Rim d.: $10.5 \mathrm{~cm}, \mathrm{~h} .: 11.5 \mathrm{~cm}$. Reddish-brown fabric (surface 2.5YR 5/6), some white inclusions. Preservation: found intact. Analogies: Hayes 1991: 203, Figs 34:13; 35:1, 4.

2. Cooking pot, narrow-mouthed, plain slopping rim, triangular at the lip, slightly grooved handle, rounded bottom, thin-walled. Rim d.: $9.8 \mathrm{~cm}$, h.: $11.5 \mathrm{~cm}$. Soft, fragile dark reddish-brown fabric (surface $2.5 \mathrm{YR} 4 / 4$, section $2.5 \mathrm{YR} 4 / 6$ ), some white inclusions. Preservation: found in pieces, almost complete. Analogies: Hayes 1991: 203, Figs $34: 13 ; 35: 1,4$.

3. Cooking pot, narrow-mouthed, plain slopping rim, rounded and outcurved at the lip, slightly grooved handle, rounded bottom, thin-walled. Rim d.: $9.8 \mathrm{~cm}$, h.: $10 \mathrm{~cm}$. Dark reddish-brown fabric (surface 2.5YR 5/6). Deformed rim, blackened bottom. Preservation: found intact. Analogies: Hayes 1991: 203, Figs 34:13; 35:1, 4.

4. Cooking pot, narrow-mouthed, plain slopping rim, triangular at the lip, centrally grooved handle, conical bottom, thin-walled. Rim d.: $10 \mathrm{~cm}$, h.: $12 \mathrm{~cm}$. Fine, fragile reddish-brown fabric (surface 2.5YR 5/6, section 2.5YR 4/6), some white inclusions. Blackened bottom and lower part of the handle. Preservation: found in pieces, almost complete, missing body fragment and upper part of the handle. Analogies: Hayes 1991: Fig. 35:4.

5. Cooking pot, narrow-mouthed, plain slopping rim, oval-sectioned handle, conical bottom, thin-walled. Rim d.: $10.3 \mathrm{~cm}$, h.: $12 \mathrm{~cm}$. Dark grey fabric (surface and section 10YR 3/1, core 2.5YR 4/6), very hard, possibly overfired; no visible inclusions. Preservation: found in pieces, almost complete, missing fragment of the body. Analogies: Hayes 1991: 203, Figs 34:13; 35:1, 4.

6. Small cooking pot, narrow-mouthed, plain slopping rim, centrally grooved handle, flattened bottom, thin-walled. Rim d.: $9.4 \mathrm{~cm}$, h.: $10 \mathrm{~cm}$. Fine reddish-brown fabric (surface and section 2.5YR 5/8), some small white inclusions. Blackened bottom. Preservation: found in pieces, almost complete, missing bottom fragment. Analogies: Hayes 1991: 203, Figs 34:13; 35:1, 4.

7. Cooking pot, narrow-mouthed, plain slopping rim, outcurved at the lip, centrally grooved handle, thin-walled. Rim d.: $11.5 \mathrm{~cm}$, h.: $13 \mathrm{~cm}$. Fine, light reddish-brown fabric (surface 2.5YR 5/6 - 4/6, section 2.5YR 5/8), some small white inclusions. Some blackening on the bottom. Preservation: found in pieces, almost complete, missing body fragment. Analogies: Hayes 1991: Fig. 36:2. 

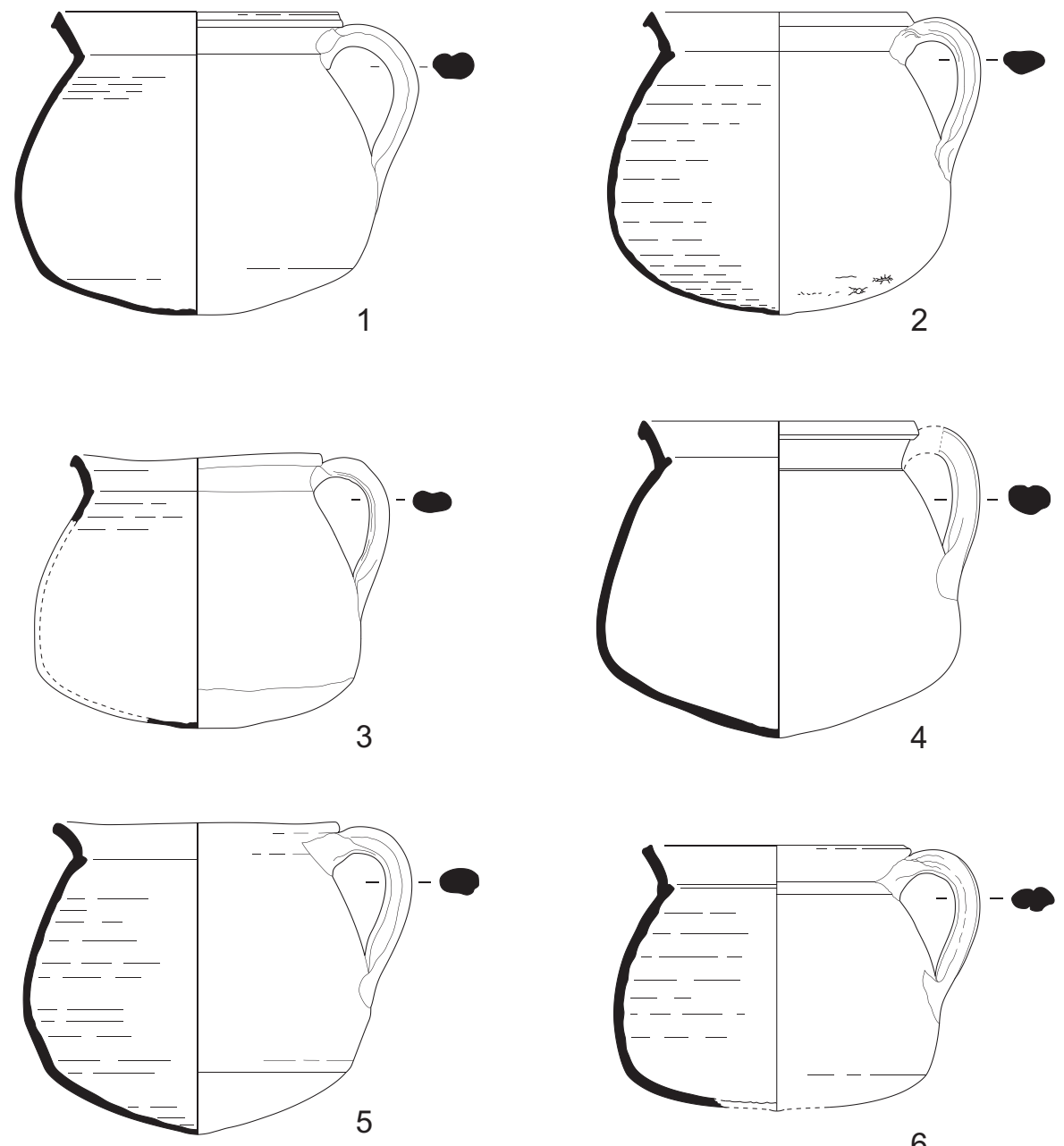

6

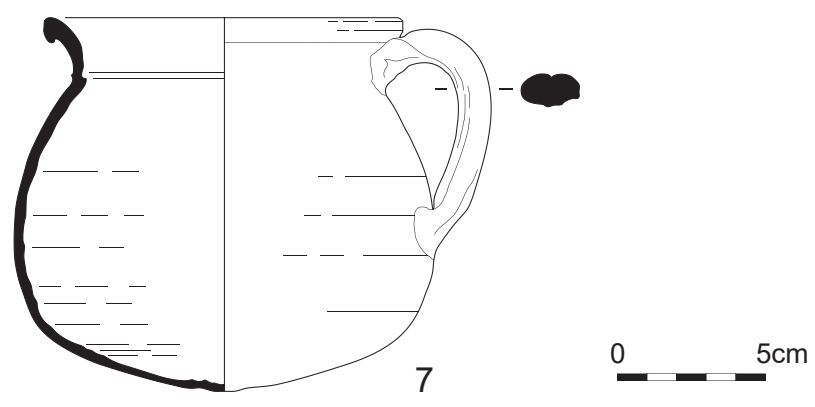

3. One-handled Cypriot cooking pots from room 22 (Drawing: M. Więch (nos 2, 4-7), M. Droste (nos 1, 3); digitizing: M. Więch). 
8. Cooking pot, narrow-mouthed, oval-sectioned handle, flat-sided. Rim d.: $10 \mathrm{~cm}$, h.: $11.5 \mathrm{~cm}$. Fine, fragile reddish-brown fabric (surface $2.5 \mathrm{YR} 5 / 6$, section $2.5 \mathrm{YR}$ 4/6), small white inclusions. Preservation: found in pieces, missing central part of the bottom. Analogies: Hayes 1991: 203, Figs 34:13; 35:1, 4.

9. Cooking pot, narrow-mouthed, grooved rim, single ridge below the neck, flattened handle with two grooves, deep rounded body, thin-walled. Rim d.: $14.8 \mathrm{~cm}, \mathrm{~h} .: 17.5 \mathrm{~cm}$. Reddish-brown fabric (surface 2.5YR 4/6), white inclusions. Blackened bottom. Preservation: found intact. Analogies: Hayes 1991: 81, 83, Figs 31:1, 3; 34:10, 11. 

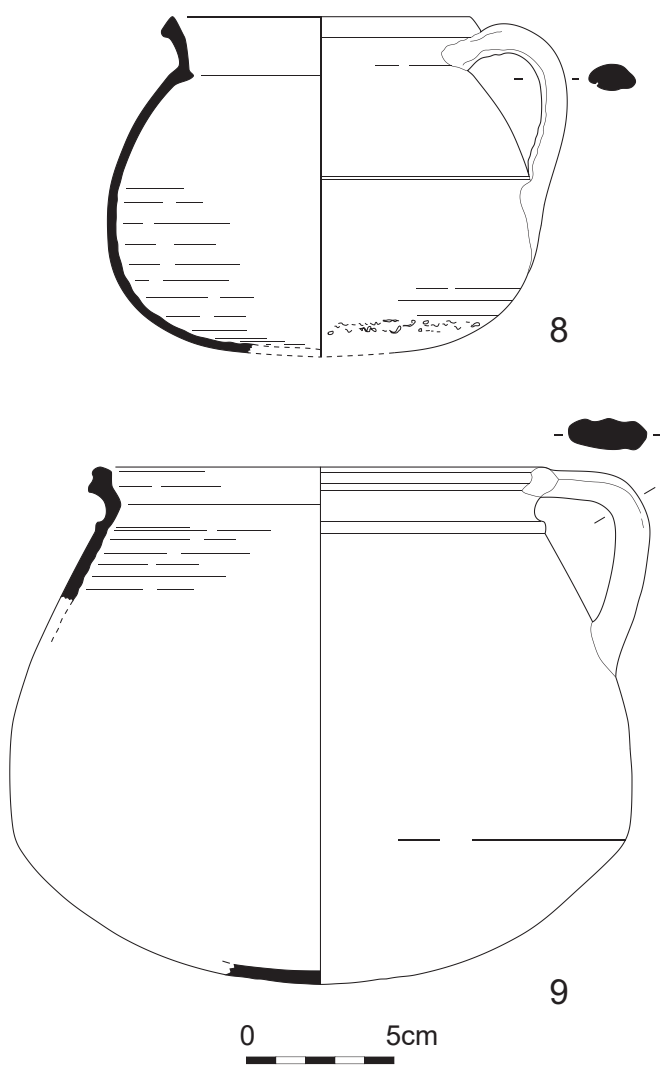

4. One-handled Cypriot cooking pots from room 23 (Drawing: M. Więch (no. 8), M. Droste (no. 9), digitizing: M. Więch). 
10. Cooking pot, narrow-mouthed, plain slopping rim, flattened at the lip, oval-sectioned looped handles, low-bellied form with flattened bottom, very thin-walled (from $0.15 \mathrm{~cm}$ ). Rim d.: $12.8 \mathrm{~cm}$, h.: $14.5 \mathrm{~cm}$. Well-fired fabric (section 2.5YR 4/8), dark grey (except the bottom) outside surface (5YR 4/1-3/1). Some blackening on the bottom. Preservation: found in pieces, complete profile, missing fragments of the rim and the body. Analogies: Hayes 1991: 82-83, Fig. 30:5 (example from the House of Dionysos has three grooves on the upper part of the body; non-Paphian origin was suggested).

11. Cooking pot, narrow-mouthed, plain slopping rim, incurved at the lip, oval-sectioned handles, low baggy shape, thick-walled. Rim d.: $13 \mathrm{~cm}$, h.: $15 \mathrm{~cm}$. Soft, reddish-brown fabric (surface 2.5YR 4/4-3/4, section 2.5YR 4/6), small white inclusions. Slightly blackened on the bottom. Preservation: missing upper part of handles. Analogies: Hayes 1991: Fig. 30:5.

12. Cooking pot, narrow-mouthed, plain slopping rim, rounded at the lip, massive looped handles round in section, deep, thick-walled. Rim d.: $11.6 \mathrm{~cm}$, h.: $14 \mathrm{~cm}$. Fine fabric, small white inclusions. One part of the body is fired reddish-brown (surface 2.5YR $5 / 6$ ) and the other dark grey. No signs of use. Preservation: found intact. Analogies: no direct parallels. 

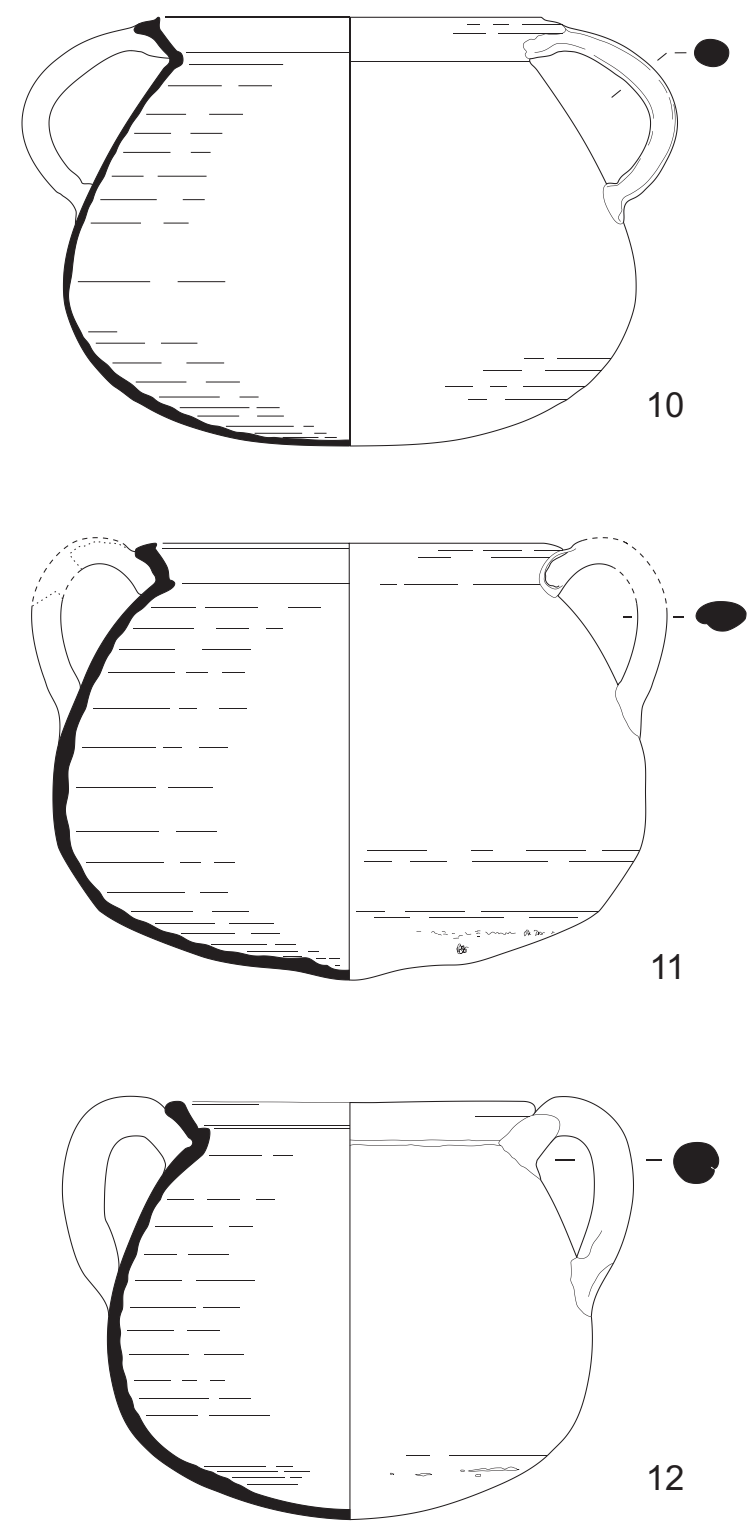

$$
0 \quad 5 \mathrm{~cm}
$$

5. Two-handled Cypriot cooking pots from room 22 (Drawing and digitizing: M. Więch). 
13. Cooking pot, narrow-mouthed, plain, flat rim, two tiny handles, deep globular body, thin-walled, ribbed. Rim d.: $13 \mathrm{~cm}$, h.: $11 \mathrm{~cm}$. Fine, compact, orange-pink fabric (surface 5YR 7/6, section 5YR 6/8). The outer side (except for the bottom) is fired smoky grey (10YR 5/1). Some golden flakes of mica visible on the surface. No signs of use in fire. Preservation: found in pieces, almost complete. Analogies: Hayes 1983: 105, Fig. 5:58-59.

14. Baking dish, wide-mouthed, plain rim, low sloping walls and a tubular handle, flat base, thick-walled. Rim d.: $27.4 \mathrm{~cm}$, h.: $4.5 \mathrm{~cm}$. A gritty, rough, pinkish-grey fabric (surface 5YR 5/3, section 5YR 6/6) with traces of golden mica. Inner surface covered with pinkish slip, coarsening on the outside of the bottom. No clear signs of use in fire. Preservation: handle is missing. Analogies: Hayes 1983: 107, 126-127, Figs 9:99-102; 18:228; 1991: 80, Figs 28:1; 34:99; Sackett, Jones 1992: P1. 188:10.

15. Baking lid, plain rim, rounded at the lip, slopping walls. Rim d.: $24.6 \mathrm{~cm}$, h.: $3.5 \mathrm{~cm}$. Fine, pinkish fabric (surface and section 5YR 6/6) with some white inclusions, rim fired dark grey. Preservation: found in pieces, missing fragment of the rim and the body. Analogies: Di Giovanni 1996: 97-99, Fig. 25; Hayes 1991: Fig. 44:22; 2009: 9, 17, Fig. 16:75; 1972: 205-207, Fig. 36 top, ARS Form 192.

16. Baking lid, plain rim, rounded at the lip, slopping walls. Rim d.: $29.6 \mathrm{~cm}$, h.: $3 \mathrm{~cm}$. Reddish-yellow fabric (surface 2.5YR 4/6, section 7.5YR 7/6). Blackened walls and round lip. Preservation: found in pieces, almost complete. Analogies: Goudineau 1970: 168, P1. II:18; Hayes 1991: 79, Fig. 27:6.

17. Orlo bifido dish, wide-mouthed, short, gently curved walls, flat bottom, no handles. Narrow groove for a lid on the rim interior. Rim d.: $42 \mathrm{~cm}$, h.: $8 \mathrm{~cm}$. Bright orange-red fabric (inner surface and section 2.5YR 6/8), compact, typical Campanian 'black sand' inclusions (Peacock fabric 1). Self-slip on the inside. The outer surface fired to smoky-grey $(10 \mathrm{YR} 4 / 1)$. No traces of use in fire. Preservation: found in pieces in several contexts (nos 46, 74, 68), missing fragment of the rim, body and central part of the bottom. Analogies: Peacock 1977: 146, 149-154; Hayes 1983: 78, Fig. 27:9; 1991: 79, Fig. 27:8-9. 

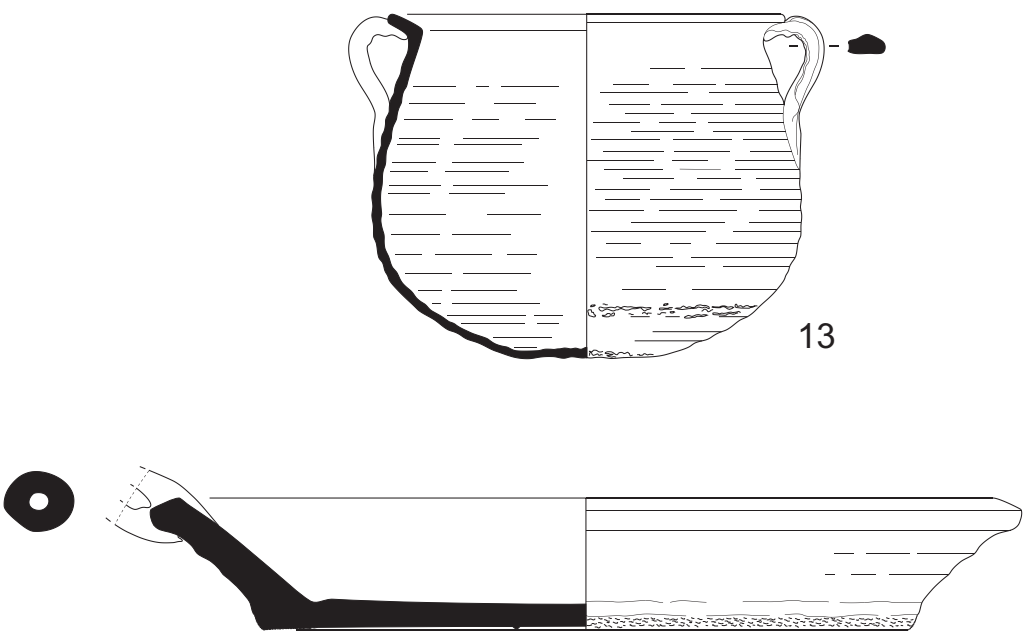

14
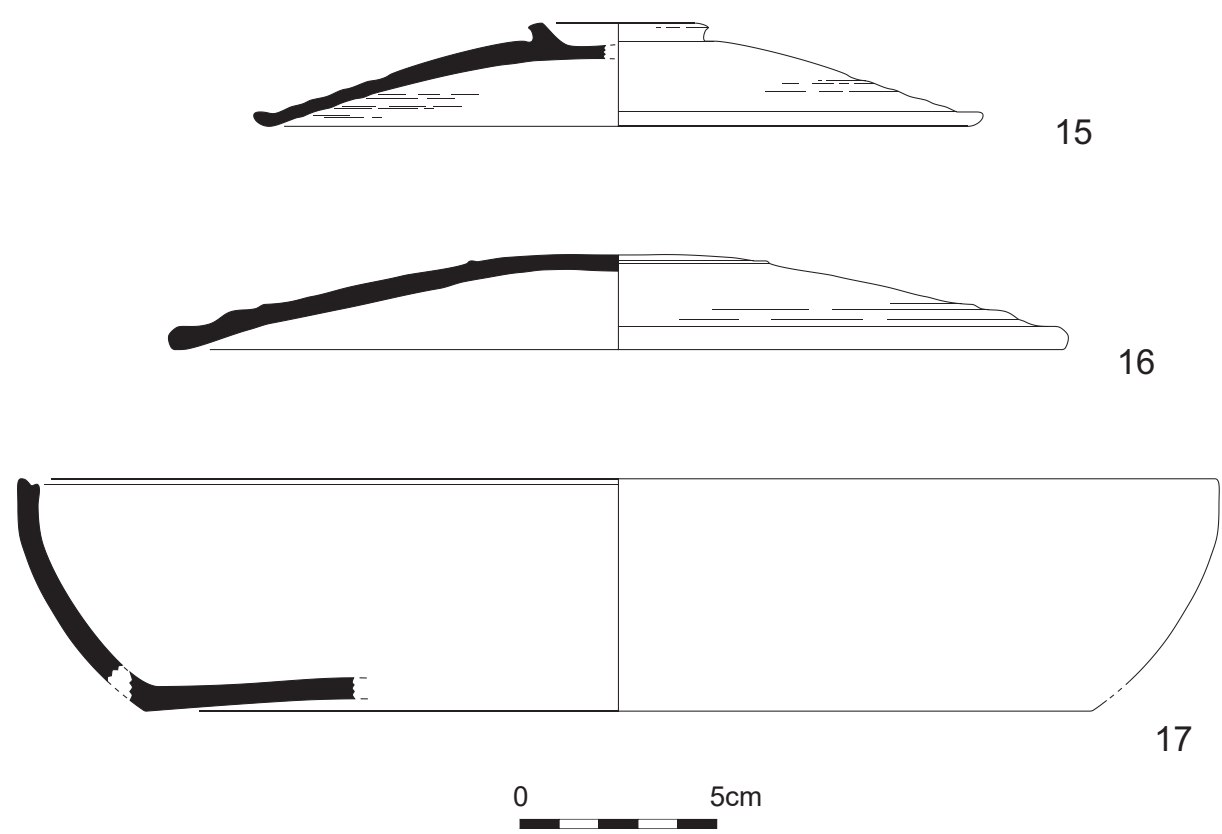

6. Aegean (nos 13-14) and Italian (nos 15-17) cooking ware vessels from room 22 (Drawing: M. Więch (nos 13-15, 17), K. Kapiec (no. 16); digitizing: M. Więch). 


\section{ÉTUDES et TRAVAUX XXX / 2017}

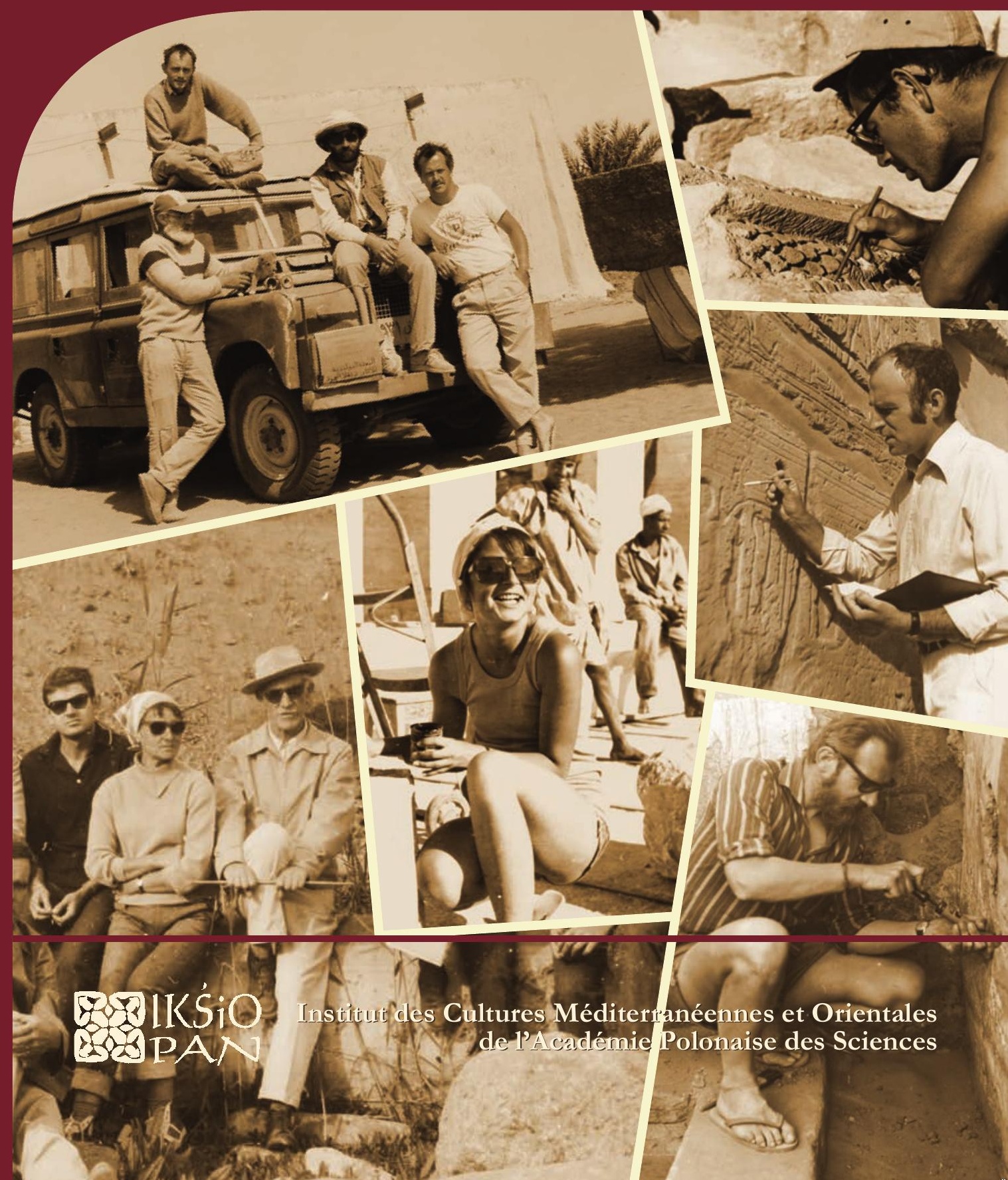




\title{
COMITÉ DE RÉDACTION SCIENTIFIQUE
}

Maciej Makowski - rédacteur en chef

Jadwiga Iwaszczuk - rédacteur et sécretaire de la rédaction

Mariusz Drzewiecki - rédacteur

Maciej G. Witkowski - rédacteur

\section{CONSEIL SCIENTIFIQUE DU JOURNAL}

M. Kobusiewicz (IAE PAS, Warszawa), E. Laskowska-Kusztal (IMOC PAS, Warszawa),

D. Michaelides (University of Cyprus, Nicosia),

J.Ch. Moretti (IRAA-MOM, Université de Lyon 2/CNRS),

D. Raue (Ägyptisches Museum der Universität Leipzig), P. Reynolds (ICREA, Barcelona),

D. Welsby (British Museum, London)

\section{COMITÉ SCIENTIFIQUE DE LECTURE}

J. Holaubek (Institut für Ägyptologie, Wien), S. Ikram (AUC, Cairo),

K. Innemée (Universiteit Leiden), J. McKenzie (Faculty of Oriental Studies, University of Oxford),

N. Strudwick (University of Cambridge), A. Loprieno-Gnirs (Universität Basel),

Ch.E. Loeben (Museen für Kulturgeschichte, Hannover), Y. Tristant (Macquarie University, Sydney),

V.W.J. van Gerven Oei (University of Aberdeen), A. Peignard-Giros (HiSoMA-MOM, Université de Lyon 2/CNRS), J.A. Ostrowski, E. Papuci-Władyka, J. Śliwa (IA JU, Kraków), R. Czerner (WUST, Wrocław), A. Ćwiek (IA AMU, Poznań), M. Wiewióra (IA NCU, Toruń), K. Domżalski

(IAE PAS, Warszawa), K.O. Kuraszkiewicz (DE FOS UW), M. Barwik, P. Bieliński, P. Dyczek, W. Godlewski, D. Ławecka, S. Rzepka, J. Żelazowski, M. Gawlikowski, J. Młynarczyk, A. Niwiński, T. Sarnowski, D. Szeląg, T. Waliszewski (IA UW, Warszawa)

\section{RÉDACTEUR THÉMATIQUE DU VOLUME \\ Barbara Lichocka}

\author{
AIDE RÉDACTION TECHNIQUE \\ Dorota Dobrzyńska, Mariusz Drzewiecki
}

REVUE DES TEXTES ANGLAIS

Jo Harper 
ÉTUDES et TRAVAUX XXX 
INSTYTUT KULTUR ŚRÓDZIEMNOMORSKICH I ORIENTALNYCH POLSKIEJ AKADEMII NAUK

\section{STUDIA i PRACE}

XXX

\section{Ro IKŚSiO \\ ESA PAN}

WARSZAWA

2017 
INSTITUT DES CULTURES MÉDITERRANÉENNES ET ORIENTALES DE L'ACADÉMIE POLONAISE DES SCIENCES

\section{ÉTUDES et TRAVAUX}

XXX

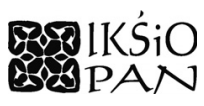

VARSOVIE

2017 
Publication scientifique financée dans le cadre du programme du Ministre de la Science et de l'Éducation Supérieure

« Programme National de Développement de l’Humanistique » pour les années 2016-2021 (projet no 3bH 150099 83)

\title{
HARODOWY PROGRAM ROZWOJU HUMANISTYKI
}

\author{
Copyright (C) \\ Instytut Kultur Śródziemnomorskich i Orientalnych PAN \\ et les Auteurs \\ Warszawa 2017
}

\author{
ISSN 2084-6762 \\ (avant $2011: 0079-3566$ ) \\ e-ISSN 2449-9579 \\ Version première en papier, imprimée en Pologne - 150 copies \\ Version électronique accessible sur \\ http://www.etudesettravaux.iksiopan.pl
}

Édition: Polskie Towarzystwo Historyczne et Wydawnictwo Neriton, Warszawa

Conception générale de couverture : J. Iwaszczuk

Photos de couverture : En haut, à gauche. Vieille Dongola 1991, S. Jakobielski

(debout à gauche), K. Pluskota (debout à droite), B. Żurawski (assis sur le camion)

et P. Wierzbicki (assis sur le camion) (de la collection de B. Żurawski)

En haut, à droite. Palmyre 1964, M. Marciniak au travail (phot. A. Dziewanowski)

Au centre. E. Laskowska-Kusztal au travail (de la collection de E. Laskowska-Kusztal)

En bas, à gauche. Tell Atrib 1962 ; de gauche : T. Biniewski, M. Marciniak, K. Kołodziejczyk,

K. Michałowski, A. Ostrasz, S. Jakobielski et S. Jasiewicz devant eux

(de la collection de IKŚSiO PAN).

En bas, à droite. Vieille Dongola 1976, S. Jakobielski nettoyant le mur (phot. M. Steinborn).

Au centre, à droite, K. Myśliwiec en train des travaux de documentation (de la collection de IKŚiO PAN) 


\section{Table des matières}

BARBARA LICHOCKA

Ergon agathon

Hartwig Altenmüller

$\mathrm{Zu}$ den Feindbildern auf den Zauberstäben des Mittleren Reiches und der Zweiten

Zwischenzeit

Nathalie Beaux

Des $m s w n s w$ de Thoutmosis III à Deir el-Bahari

Briant Bohleke, Nigel Strudwick

A Label for Opening of the Mouth Implements from the Burial of Senneferi (TT99)

and Remarks on the Ritual

Rosa Maria Bonacasa Carra, Nicola Bonacasa

Nuovi dati sugli edifici termali di Sabratha

EDWARD BROVARSKI

A Fragmentary Carrying Chair Scene in Salt Lake City, Utah

Julia Burdajewicz

Wall Painting Decoration from the North-West Church in Hippos-Sussita

of the Decapolis

Mariusz BURDAJEWICZ

From Pagan Temple to Church in Late Antiquity Palestine. A View from

Hippos-Sussita

MAREK ChlodNicki

Early Dynastic Bead Workshops at the Central Kom of Tell el-Farkha.

Patryk ChudziK, Mariusz Caban

Observations on the Architecture of the Tomb of Horhotep in Western Thebes

Krzysztof M. Cialowicz

New Discoveries at Tell el-Farkha and the Beginnings of the Egyptian State.

Amr EL-TiebI

Four Wooden New Kingdom Female Statuettes in the Egyptian Museum, Cairo 


\section{Naguib KanaWATI}

Ritual Marriage Alliances and Consolidation of Power in Middle Egypt during the Middle Kingdom

Adam Łajtar, Jolanta Mlynarczyk

A Faction Acclamation Incised on a Pithos Found Near the North-West Church at Hippos (Sussita)

Adam ŁaJTAR, Grzegorz OchaŁa

Two Private Prayers in Wall Inscriptions in the Faras Cathedral

Adam Łajtar, Anna Poludnikiewicz

Medicinal Vessels from Tell Atrib (Egypt)

JaCeK Michniewicz, Jolanta MlynarczyK

Petrographic Variability of the Fabrics of Wine Jars from Sha'ar-Ha Amakim as a Reflection of Differences in Their Provenance and Chronology

Iwona ModrzewsKa-PianetTI

Les importations d'amphores Dressel 20 en Gaule Cisalpine

Arthur SEgal

Samaria-Sebaste. Portrait of a polis in the Heart of Samaria 409

JOACHIM ŚLIWA

The Motif of a 'Blind Harper' in an Unexpected Place

MONIKA WIĘCH

Searching for the Kitchen in the Early Roman Phase of the 'Hellenistic' House at Nea Paphos (Cyprus)

Abréviations 
THE VOLUME IS PUBLISHED TO CELEBRATE

THE $60^{\text {TH }}$ ANNIVERSARY

OF THE ESTABLISHMENT OF

THE RESEARCH CENTRE FOR MEDITERRANEAN ARCHAEOLOGY POLISH ACADEMY OF SCIENCES

FOUNDED IN 1956

WHOSE MISSION IS CONTINUED BY

THE INSTITUTE OF MEDITERRANEAN AND ORIENTAL CULTURES

OF THE POLISH ACADEMY OF SCIENCES 